\title{
Usaha Tani dan Tataniaga Kumis Kucing di Kampung Ciwaluh dan Kampung Lengkong, Kabupaten Bogor
}

\author{
Farm Management and Market Chains of Java Tea Plant at Ciwaluh Village \\ and Lengkong Vilage, Bogor Regency \\ Friska Sitorus $^{* 1}$, Ani Suryani², dan Budi Suharjo ${ }^{3}$ \\ ${ }^{1}$ Magister Pengembangan Industri Kecil Menengah SPs IPB \\ Jl. Raya Pajajaran, Kampus IPB Baranangsiang, Bogor 16144 \\ ${ }^{2}$ Departemen Teknologi Industri Pertanian, Fakultas Teknologi Pertanian, Institut Pertanian Bogor \\ Jl. Kamper, Kampus IPB Darmaga Bogor 16680 \\ ${ }^{3}$ Departemen Matematika, Fakultas Matematika dan Ilmu Pengetahuan Alam, Institut Pertanian Bogor \\ Jl. Lingkar Kampus, Kampus IPB Darmaga, Bogor 16680
}

\begin{abstract}
ABSTRAK
Petani produsen biofarmaka kumis kucing tidak dapat mengandalkan budi daya tanaman ini sebagai penghasilan utama. Penelitian ini bertujuan memahami permasalahan dalam pemasaran kumis kucing sejak dari perkebunan di Kampung Ciwaluh dan Kampung Lengkong sampai ke rantai pemasaran terakhir.Metode penelitian yang digunakan adalah kuesioner deskriptif, analisis biaya usaha tani dan pendekatan rantai pemasaran. Hasil analisis biaya usaha tani per $1.000 \mathrm{~m}^{2}$ menunjukkan bahwa petani di Kampung Lengkong mendapatkan keuntungan baru di tahun kedua Rp294.000 untuk terna basah dan Rp774.000 untuk terna kering. Petani Kampung Ciwaluh pada tahun pertama sudah mendapat keuntungan, jika menjual dalam bentuk kering Rp399.000. Di tahun kedua hingga kelima petani mendapat keuntungan Rp294.000 untuk penjualan terna basah dan Rp1.494.000 untuk penjualan terna kering. Margin rantai pemasaran menunjukkan perbedaan harga di tingkat produsen dan konsumen tidak terlalu jauh. Margin pemasaran di Kampung Ciwaluh 50,36\% dan Kampung Lengkong $58,36 \%$. Margin keuntungan petani sekitar $80 \%$, tertinggi diantara semua pelaku tataniaga kumis kucing di wilayah ini. Hasil analisis ini menunjukkan saluran pemasaran sudah efisien namun tidak menguntungkan petani, tidak memiliki kekuatan dalam menentukan harga jual dan tidak ada pilihan pasar. Untuk itu harus ada bantuan kepada petani kumis kucing untuk memperbaiki pemasaran.
\end{abstract}

Kata kunci: kumis kucing, pemasaran, tataniaga

ABSTRACT

Farmer of cat's whisker medicinal plant is unable to rely on cultivation of this plant as main income. The study aims to understand the problems in the marketing of cat's whiskers from plantations in Ciwaluh Village and Lengkong Village to the last marketing chain. The research methodology used is descriptive questionnaire, cost analysis of farming and marketing chain approach. The result of farm cost analysis per $1.000 \mathrm{~m}^{2}$ shows that farmers in Lengkong Village in the first year have not gained profit. The farmers receive it in the second to fifth year of Rp294.000 for fresh leaves and Rp774.000 for dried leaves.. While farmers Ciwaluh Village in the first year has been benefitedof Rp399,000 if it sells the dried leaves. In the 2nd to 5th year the farmers receive a profit of Rp294.000 for sales of fresh leaves and Rp1.494.000 for dried leaves. Based on the marketing chain margin approach shows that price differences at producer and consumer level are similar. Its worth $50.36 \%$ in Ciwaluh Village and $58.36 \%$ in Lengkong Village. The profit margin of farmers is about $80 \%$, the highest among thesesupply chain agents. The analysis shows that marketing channels are efficient but not beneficial to farmers, they have no power in determining the selling price and there is no market option. For that there must be assistance to cat's whiskers farmers to improve marketing.

Key words: cat's whisker, marketing, marketing channel

\footnotetext{
*) Korespondensi:

Jl. Wijaya Kusuma R5 Taman Yasmin , Bogor; email: ifyg06@gmail.com
} 


\section{PENDAHULUAN}

Permintaan bahan tanaman obat dengan memanfaatkan tanaman berkhasiat obat (biofarmaka) semakin bertambah, baik di negara maju maupun di negara berkembang. Keadaan ini dilatarbelakangi pemahaman masyarakat untuk memiliki gaya hidup kembali ke alam (back to nature). Akibatnya permintaan dan perdagangan komoditas biofarmaka semakin meningkat. Menurut Food and Agriculture Organization (2003), pertumbuhan ini digerakkan sebagian oleh minat dalam obat-obatan komplementer di negara industri dan sebagian dari minat industri farmasi dunia.

Kecenderungan tersebut membuka peluang yang menguntungkan bagi Indonesia yang dianugerahi kelimpahan kekayaan hayati (biodiversity). Tidak kurang dari $80 \%$ spesies tanaman berkhasiat obat yang diperlukan dunia ada di hutan hujan tropis Indonesia (UNIDO, 2006). Bahan baku biofarmaka tersebut digunakan oleh banyak sektor industri dan dapat mendatangkan pemasukan ekonomi bagi negara. FAO (2003) menyebutkan setidaknya ada delapan sektor industri berbasis tanaman berkhasiat obat. Meskipun Indonesia memiliki kekayaan biodiversitas yang tinggi, namun baru sebagian kecil saja yang dibudidayakan secara intensif. Sedangkan sisanya diperoleh dari tanaman liar (wild harvesting) sehingga kegiatan bioprospeksi cenderung mengakibatkan eksploitasi (Hidayat, 2006; Pribadi, 2009; Zuraida et al, 2009; Poerwanto, 2014). Hal ini juga yang menjadi kekhawatiran di negara-negara berkembang lain yang mengandalkan tanaman obat bagi kesehatan penduduknya (De Silva, 2003). Oleh sebab itu dapat dikatakan bahwa komoditas biofarmaka memiliki dua aspek menguntungkan, yakni aspek medik dan ekonomi.

Dibalik keunggulan komparatif berupa kekayaan hayati tersebut, FAO memandang perlu adanya keberlangsungan produksi biofarmaka bagi kesejahteraan manusia, terutama bagi penduduk di negara berkembang (Van Seters, 2003). Indonesia termasuk negara yang rawan ancaman kepunahan tanaman obat, mengingat banyak jenis tanaman berkhasiat obat yang diperoleh dengan cara penambangan, yakni dipanen secara langsung dari alam. Masih sedikit jenis tanaman berkhasiat obat yang dibudidayakan.

Terdapat tantangan yang mesti dihadapi dalam pengembangan bahan baku obat alam agar menjadi sumber kekayaan berkelanjutan. Peraturan Menteri Kesehatan RI no 88 tahun 2013 tentang Rencana Induk Pengembangan Bahan Baku Obat Tradisional menyebutkan beberapa kendala utama. Kendala tersebut berkenaan dengan mutu, kuantitas dan kontinuitas bahan baku. Banyak bahan baku tanaman obat yang belum dibudidaya dan teknik pengolahan pasca panen yang dikerjakan masih di bawah standar cara pengolahan yang baik.

Salah satu komoditas tanaman obat yang telah lama dibudidayakan di Desa Wates Jaya, Kecamatan Cigombong, Kabupaten Bogor adalah tanaman kumis kucing. Studi tentang kumis kucing menunjukkan ada ratusan kandungan senyawa kimia dalam tumbuhan ini yang berkhasiat bagi kesehatan manusia. Kandungan kimia tersebut diantaranya garam kalium, saponin, alkaloid, minyak atsiri, glikosida, orthosiponin, tanin, flavonoid, asam organik, terpenoid. (Kartasubrata, 2010; Pattamadilok, 2011; Adnyana, 2013). Upaya budidaya kumis kucing telah turun temurun sekitar tiga generasi, tetapi petani tidak dapat menjadikannya sebagai pendapatan utama. Pemasaran komoditas sangat tergantung pada permintaan tengkulak, sedangkan tengkulak mendapat informasi pasar dari eksportir dan industri obat. Kajian mengenai saluran pemasaran bahan baku obat dari daun kumis kucing diharapkan memberi gambaran permasalahan yang terjadi. Deskripsi kondisi yang ada dapat mengukur potensi dan daya saingnya sebagai komoditas pertanian yang prospektif bagi produsen yakni petani.

Menurut Kotler (2006), saluran pemasaran (saluran distribusi) adalah sekelompok organisasi yang saling tergantung membantu membuat produk atau jasa tersedia untuk digunakan atau dikonsumsi oleh konsumen atau pengguna bisnis. Hal ini dapat disimpulkan bahwa dalam setiap mata rantai yang terlibat terdapat kegiatan penambahan nilai dan setiap lembaga yang terlibat memperoleh keuntungan berbeda.

Dilihat dari jauh pendeknya rantai distribusi, saluran pemasaran dapat dikelompokkan menjadi dua (Kotler, 2006) yakni: (1) Saluran pemasaran langsung (direct marketing channel) adalah saluran pemasaran dimana tidak terdapat tingkat perantara atau penyalur; (2) Saluran distribusi tidak langsung (indirect marketing channel), yaitu perusahaan dalam mendistribusikan produknya menggunakan satu atau beberapa tingkat agen perantara sebelum sampai ke tangan konsumen. 
Secara khusus penelitian ini bertujuan (1) Mempelajari mata rantai pemasaran kumis kucing dan pembentukan harga di Kampung Ciwaluh dan Kampung Lengkong, Desa Wates Jaya; (2) Memperoleh gambaran usaha tani dan tataniaga kumis kucing dan prospeknya.

\section{METODE PENELITIAN}

Lokasi penelitian usaha tani dan tataniaga kumis kucing dilaksanakandi Kampung Ciwaluh dan Kampung Lengkong, Desa Wates Jaya, Kecamatan Cigombong, Kabupaten Bogor Propinsi Jawa Barat. Analisis data dilakukan secara deskriptif. Data yang diperoleh dianalisis untuk mengetahui biaya dan pendapatan petani dalam budi daya kumis kucing. Dari segi tataniaga komoditas, pendekatan marjin pemasaran dilakukan untuk mengetahui efisiensi suatu rantai pemasaran.

\section{Marjin Pemasaran (Marketing Margin)}

Dari perolehan data di lapangan dianalisis secara kuantitatif untuk mengetahui perolehan marjin pemasaran (marketing margin) dari setiap lembaga pemasaran. Penelitian kualitatif dimaksudkan untuk menguraikan saluran pemasaran dan peran pelaku/lembaga pemasaran yang terlibat.

Marjin pemasaran atau marjin tataniaga atau marjin kotor menunjukkan selisih harga dari dua tingkat rantai pemasaran. Pendekatan analisis menggunakan rumus:

$\mathrm{Mi}=\mathrm{Psi}-\mathrm{Pbi}$

Keterangan:

$\mathrm{Mi}=$ marjin tataniaga di tingkat ke-I $(\mathrm{Rp} / \mathrm{kg})$

$\mathrm{Psi}=$ harga jual pasar di tingkat $\mathrm{ke}-\mathrm{i}(\mathrm{Rp} / \mathrm{kg})$

$\mathrm{Pbi}=$ harga beli pasar di tingkat ke-I $(\mathrm{Rp} / \mathrm{kg})$

$\mathrm{Mi}=\mathrm{Li}+\pi \mathrm{i}$

Keterangan:

$\mathrm{Li}$ = biaya lembaga pemasaran pada tingkat ke-i

$\pi \mathrm{i}=$ keuntungan lembaga pemasaran pada tingkat ke-i

Dari kedua persamaan diatas, maka diperoleh:

$\mathrm{Psi}-\mathrm{Pbi}=\mathrm{Li}+\pi \mathrm{i}$

Keuntungan Lembaga pemasaran pada tingkat ke $-\mathrm{i}$

$\pi \mathrm{i}=\mathrm{Psi}-\mathrm{Pbi}-\mathrm{Li}$

Suatu sistem distribusi pemasaran dikatakan efisien jika besarnya tingkat marjin pemasar- an bernilai < 50\% dari tingkat harga yang dibayarkan konsumen. Sementara yang dimaksudkan dengan marjin keuntungan adalah besarnya keuntungan pada setiap titik rantai pemasaran dibandingkan dengan marjin pemasaran pada titik rantai pemasaran tersebut.

\section{Analisis Farmer's Share}

Farmer's market share digunakan untuk membandingkan harga yang dibayar konsumen terhadap harga produk yang diterima petani. Pada umumnya, kecilnya persentase harga konsumen yang diterima petani menunjukkan tataniaga kurang efisien (Nasruddin dan Musyadar 2010). Besarnya nilai bagian petani dapat dihitung berdasarkan rumus berikut:

$$
\text { Farmer's Share }=\operatorname{Pf} /(\operatorname{Pr}) \times 100 \%
$$

Keterangan:

$\mathrm{Pf}=$ harga di tingkat petani

$\operatorname{Pr}=$ harga yang dibayarkan konsumen akhir

\section{Return Cash Ratio}

Perbandingan penerimaan dan biaya yang dikeluarkan petani dalam satu tahun dapat dirumuskan sebagai berikut:

$\mathrm{R} / \mathrm{C}>1$

Keterangan:

$\mathrm{R}=$ total penerimaan

$\mathrm{C}=$ total biaya

Usaha tani dapat dikatakan menguntungkan jika hasil perhitungan yang diperoleh lebih dari 1 .

\section{HASIL DAN PEMBAHASAN}

\section{Karakteristik Petani dan Kondisi Riil Perkebun- an Kumis Kucing}

Petani yang menjadi responden dalam penelitian adalah 20 orang dari Kampung Lengkong dan 10 orang dari Kampung Ciwaluh. Kampung Lengkong merupakan RT 01 dan RT 02, RW 05 dari Desa Wates Jaya. Kampung Ciwaluh merupakan RT 03 dan RT 04, RW 05 dari Desa Wates Jaya.

Usia responden berkisar 35-60 tahun. Pendidikan terakhir rataan SD dan telah berpengalaman dalam usaha tani kumis kucing selama lebih dari 20 tahun. Semua petani membudidaya kumis kucing di lahan perkebunan secara polikultur. Petani melakukan usaha tani kumis kucing untuk meneruskan yang telah dirintis orangtua.

Jenis lahan yang dimiliki petani beragam. Petani menggarap pada tegalan, sawah, kebun 
dan kolam ikan air tawar, mendapatkan data yang akurat tentang luasan lahan yang diperuntukan khusus bagi tanaman kumis kucing relatif sulit. Gabungan luasan lahan yang dimiliki sekitar 1-6 Ha per kepala keluarga (KK).

Sistem budi daya dan pasca panen kumis kucing yang diterapkan petani di Kampung Ciwaluh dan Kampung Lengkong masih sederhana. Pola tanam dilakukan secara polikultur, yaitu disamping kebun kumis kucing, petani menanam palawija, sayur-sayuran, kopi, kapulaga dan buah-buahan. Hal lainnya beberapa petani menyadap getah pinus untuk dijual.

Kumis kucing yang ditanam di lokasi penelitian adalah yang berbunga putih. Penanaman menggunakan stek batang sebagai benih yang diperoleh dari sesama petani seharga Rp1.000/kg. Untuk $1.000 \mathrm{~m}^{2}$ lahan diperlukan sekitar 200-250 kg stek batang. Petani memakai pupuk kandang dalam penyiapan lahan. Jarak tanam yang dilakukan $40 \times 40 \mathrm{~cm}$ hingga $60 \times 60 \mathrm{~cm}$.

Responden di kedua kampung yang menjadi lokasi penelitian menyatakan tidak menemui kendala dalam budi daya kumiskucing. Tanaman ini dapat tumbuh baik dengan matahari penuh maupun tempat teduh, sehingga di lokasi penelitian banyak ditemui tanaman kumis kucing disela oleh tegakan tanaman kopi, pisang atau tanaman tinggi lainnya. Pemupukan awal setelah menyiapkan lahan hanya memerlukan pupuk kandang, tidak memakai pupuk kimia, Tanaman ini juga tidak memerlukan perawatan intensif, hanya sesekali membersihkan gulma dan pemberian pupuk setiap habis panen.

\section{Karakteristik Tengkulak}

Tidak banyak tengkulak yang menjadi agen pemasaran komoditas kumis kucing karena serapan bahan baku ini untuk keperluan industri bukan pengecer. Berbeda dengan tengkulak lain di wilayah tersebut yang menjual komoditas sayur dan palawija.

Tengkulak yang diwawancarai berusia 4065 tahun. Seluruh tengkulak berjenis kelamin pria dan seorang kepala rumah tangga. Pengalaman menekuni pekerjaan ini antara 10-30 tahun. Ketiga tengkulak memiliki kesamaan karakteristik dalam menjalankan usahanya. Semua dijalankan di area yang sama dengan tempat kediaman masingmasing. Tersedia tempat parkir untuk kendaraan besar seperti truk dan ruang memadai untuk meletakkan timbangan duduk serta hasil-hasil panen dalam karung. Luasan ruang usaha antara $20 \mathrm{~m}^{2}-50 \mathrm{~m}^{2}$
Seluruh pedagang responden telah menjalin kerjasama dengan eksportir masing-masing. Seperti tengkulak di Tenjoayu menjadi pemasok bagi eksportir tujuan negara Jepang, tengkulak di Pasar Cicurug menjadi pemasok bagi tiga eksportir beberapa negara Eropa dan tengkulak di Pasir Buncir menjadi pemasok eksportir dengan negara tujuan Prancis. Para eksportir mengandalkan kumis kucing yang berasal dari Kabupaten Bogor dan Kabupaten Sukabumi, karena kadar sinensetin sesuai dengan harapan. Pengalaman dan relasi kerjasama membuat para tengkulak sudah mengerti persyaratan yang dikehendaki eksportir, seperti cara pengemasan dan mutu simplisia yang dikehendaki.

Tengkulak sebagai agen perantara (middleman) dalam saluran pemasaran menemui permasalahan, baik dari rantai hulu (produsen) maupun hilir (konsumen). Kendala yang ditemui dalam menjalankan usaha ini berkaitan dengan petani sebagai produsen adalah soal mutu, kuantitas dan kontinuitas pasokan. Hal ini sesuai dengan kendala yang disebutkan dalam Peraturan Menteri Kesehatan RI no 88 tahun 2013. Tengkulak sering menemui petani yang tidak melakukan sortasi dengan benar atau proses penjemuran yang tidak maksimal, sehingga tengkulak memutuskan mengurangi harga beli bahkan menolak/mengembalikan. Kendala kuantitas dan kontinuitas erat kaitannya dengan pola usaha tani. Permintaan eksportir untuk sekali pembelian sekitar 12 ton kadang tidak terpenuhi. Petani masih menganggap usaha tani tanaman ini sebagai pendapatan sampingan

Permasalahan dengan konsumen sebagai rantai terakhir dalam saluran berkaitan dengan masalah kepercayaan. Tengkulak mendapatkan pembayaran dalam dua tahap. Pembayaran pertama berupa uang muka dari eksportir dan akan dilunasi setelah buyer (negara tujuan ekspor) menerima barang. Tengkulak rentan ditipu negara pengimpor terlebih karena tidak ada kontrak yang mengikat antara kedua pihak. Pengalaman tersebut terjadi khususnya dengan eksportir dari luar negeri.

\section{Pemasaran Kumis Kucing}

Pada bulan ketiga setelah ditanam, petani sudah dapat melakukan panen. Seterusnya tanaman ini dapat dipanen setiap bulan sekali. Namun dengan pertimbangan kondisi harga jual, ongkos panen dan usaha pertanian lain, disamping kumis kucing, petani tidak melakukan panen secara rutin. Responden di kedua kampung 
juga tidak memiliki kebiasaan untuk menyimpan simplisia semua komoditas perkebunan yang diupayakan.

Dari Tabel 1 terlihat bahwa kebanyakan petani responden melakukan panen empat kali setiap tahunnya. Frekuensi panen ini sangat rendah dibandingkan kondisi ideal tanaman yang bisa dipanen setiap bulan. Seperti telah dijelaskan sebelumnya dengan pertimbangan alasan tertentu, petani memutuskan tidak melakukan panen secara rutin. Data ini yang digunakan menghitung analisis pendapatan petani untuk menentukan potensi usaha tani kumis kucing.

Tabel 1. Frekuensi panen

\begin{tabular}{ccccc}
\hline \multirow{2}{*}{ Panen/tahun } & \multicolumn{2}{c}{ Kp. Lengkong } & \multicolumn{2}{c}{ Kp. Ciwaluh } \\
\cline { 2 - 5 } & Jumlah & $\%$ & Jumlah & $\%$ \\
\hline 3 & 7 & 35 & 0 & 0 \\
4 & 10 & 50 & 6 & 60 \\
10 & 1 & 5 & 4 & 40 \\
15 & 1 & 5 & 0 & 0 \\
16 & 1 & 5 & 0 & 0 \\
\hline Jumlah & 20 & 100 & 10 & 100
\end{tabular}

Saluran pemasaran (saluran distribusi) adalah sekelompok organisasi yang saling tergantung yang membantu membuat produk atau jasa tersedia untuk digunakan atau dikonsumsi oleh konsumen atau pengguna bisnis. Sebanyak 100\% petani responden di kedua kampung menyalur- kan hasil panennya ke pedagang pengumpul/ tengkulak langganan kampung masing-masing.

Kegiatan pemasaran hasil panen dari kumis kucing di Kampung Lengkong dan Kampung Ciwaluh memiliki saluran yang hampir sama. Seluruh saluran tersebut bermuara kepada eksportir, dan rinciannya sebagai berikut:

1. Kampung Ciwaluh, petani menjual kepada pedagang pengumpul, yang bertindak juga sebagai tengkulak, untuk selanjutnya dijemput oleh eksportir (Gambar 1).

2. Kampung Lengkong, petani menyerahkan panen kepada pedagang pengumpul setingkat kampung/desa kemudian dijual kepada tengkulak hasil bumi yang akan menjualnya kepada eksportir (Gambar 2).

Tabel 2 dan 3 menunjukkan perbandingan pemasaran komoditas kumis kucing dalam bentuk segar dan kering di dua saluran pemasaran berbeda. Gambaran biaya yang diperhitungkan meliputi biaya usaha tani dan biaya pasca panen. Perhitungan analisis usaha tani ini dalam skala $1.000 \mathrm{~m}^{2}$. Analisis usaha tani pada tahun ke-2 hingga ke-5 akan sama nilainya, karena tanaman kumis kucing baru mengalami penanaman kembali jika telah mencapai usia tidak produktif (6 tahun).

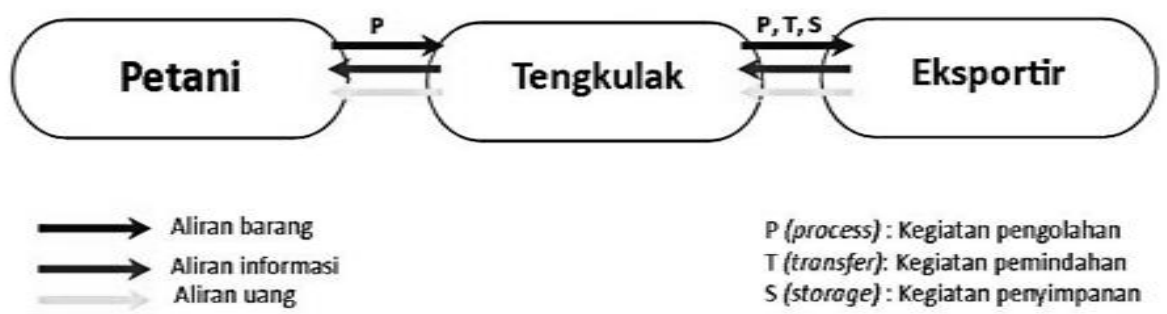

Gambar 1. Saluran pemasaran kumis kucing di Kampung Ciwaluh

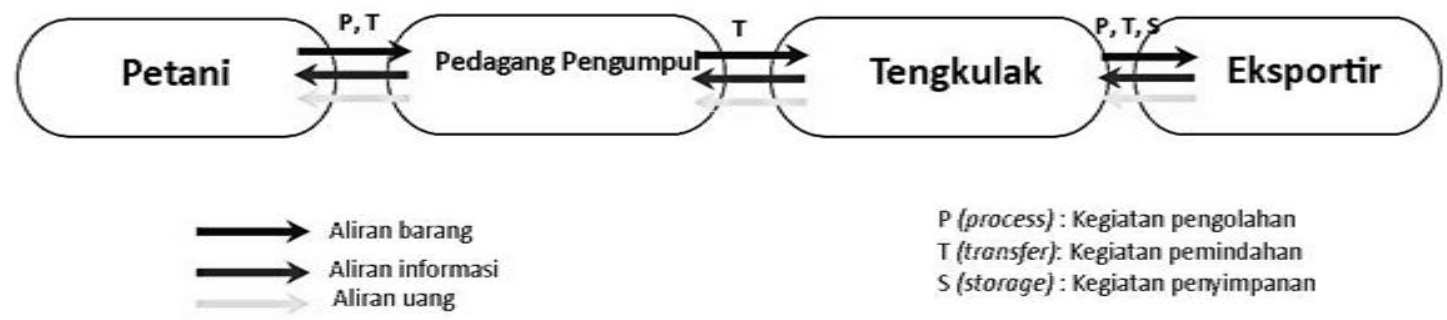

Gambar 2. Saluran pemasaran kumis kucing di Kampung Lengkong 
Melalui hasil perhitungan ini diperoleh bahwa petani yang menjual dalam bentuk kering di saluran pemasaran Kampung Ciwaluh sudah mendapat keuntungan di tahun pertama (R/C ratio bernilai lebih dari 1). Sementara pemasaran kumis kucing dalam bentuk segar di kedua saluran baru mendapatkan keuntungan pada tahun ke-2. Hal yang sama terjadi pada pemasaran kumis kucing kering di saluran Kampung Lengkong baru memberi keuntungan pada tahun ke-2.
Pemasaran komoditas segar di saluran Kampung Lengkong memiliki rasio yang tidak terlalu jauh dengan yang sudah dikeringkan. Ratio R/C kumis kucing basah di tahun pertama 0,724 dan dalam bentuk kering 0,919. Pada tahun kedua rasio yang diperoleh untuk kumis kucing basah 1,163 dan dalam bentuk kering 1,207. Hal tersebut diartikan bahwa usaha tani di Kampung Lengkong untuk menghasilkan kumis kucing simplisia tidak terlalu menguntungkan bagi petani.

Tabel 2. Analisis usaha tani di Kampung Lengkong

\begin{tabular}{|c|c|c|c|c|c|}
\hline Uraian & Satuan & Volume & $\begin{array}{c}\text { Harga } \\
\text { satuan } \\
(\mathrm{Rp})\end{array}$ & $\begin{array}{c}\text { Tahun } 1 \\
(\mathrm{Rp})\end{array}$ & $\begin{array}{c}\text { Tahun } 2 \\
(\mathrm{Rp}) \\
\end{array}$ \\
\hline \multicolumn{6}{|l|}{ Tenaga kerja } \\
\hline Pembukaan lahan & $\mathrm{HOK}$ & 10 & 25.000 & 250.000 & - \\
\hline Pengolahan tanah & $\mathrm{HOK}$ & 5 & 25.000 & 125.000 & - \\
\hline Pemupukan dasar & $\mathrm{HOK}$ & 5 & 25.000 & 125.000 & - \\
\hline Penanaman bibit & $\mathrm{HOK}$ & 3 & 25.000 & 75.000 & - \\
\hline Pemupukan lanjutan $4 x /$ tahun & $\mathrm{HOK}$ & 16 & 25.000 & 400.000 & 400.000 \\
\hline Penyiangan & $\mathrm{HOK}$ & 8 & 25.000 & 200.000 & 200.000 \\
\hline Panen $4 x /$ tahun & $\mathrm{HOK}$ & 16 & 50.000 & 800.000 & 800.000 \\
\hline Jumlah biaya tenaga kerja terna basah & & & & 1.975 .000 & 1.400 .000 \\
\hline Sortir dan jemur & $\mathrm{HOK}$ & 36 & 25.000 & 900.000 & 900.000 \\
\hline Biaya angkut & & 4 & 40.000 & 160.000 & 160.000 \\
\hline Jumlah biaya tenaga kerja terna kering & & & & 3.035 .000 & 2.460 .000 \\
\hline \multicolumn{6}{|l|}{ Bahan } \\
\hline Bibit siap tanam & $\mathrm{Kg}$ & 200 & 1.000 & 200.000 & - \\
\hline Pupuk kandang & $\mathrm{Kg}$ & 130 & 3.000 & 390.000 & 390.000 \\
\hline Jumlah biaya bahan & & & & 590.000 & 390.000 \\
\hline \multicolumn{6}{|l|}{ Peralatan } \\
\hline Cangkul & Buah & 2 & 65.000 & 130.000 & - \\
\hline Kored & Buah & 2 & 35.000 & 70.000 & - \\
\hline Sabit & Buah & 2 & 25.000 & 50.000 & - \\
\hline Parang & Buah & 2 & 35.000 & 70.000 & - \\
\hline Waring & Buah & 8 & 2.000 & 16.000 & 16.000 \\
\hline Jumlah biaya peralatan & & & & 336.000 & 16.000 \\
\hline \multicolumn{6}{|l|}{ Total biaya usaha tani } \\
\hline Terna basah & & & & 2.901 .000 & 1.806 .000 \\
\hline Terna kering & & & & 3.961 .000 & 2.866 .000 \\
\hline \multicolumn{6}{|l|}{ Hasil Produksi } \\
\hline \multicolumn{6}{|l|}{ Terna segar/ basah } \\
\hline $4 x$ panen/tahun & $\mathrm{Kg}$ & 1400 & 1.500 & 2.100 .000 & 2.100 .000 \\
\hline Pendapatan bersih & & & & $(801.000)$ & 294.000 \\
\hline $\mathrm{R} / \mathrm{C}$ ratio & & & & 0,724 & 1,163 \\
\hline \multicolumn{6}{|l|}{ Terna kering } \\
\hline $4 x$ panen/tahun & $\mathrm{Kg}$ & 280 & 13.000 & 3.640 .000 & 3.640 .000 \\
\hline Pendapatan bersih & & & & $(321.000)$ & 774.000 \\
\hline $\mathrm{R} / \mathrm{C}$ ratio & & & & 0,919 & 1,207 \\
\hline
\end{tabular}


Tabel 3. Analisis usaha tani di Kampung Ciwaluh

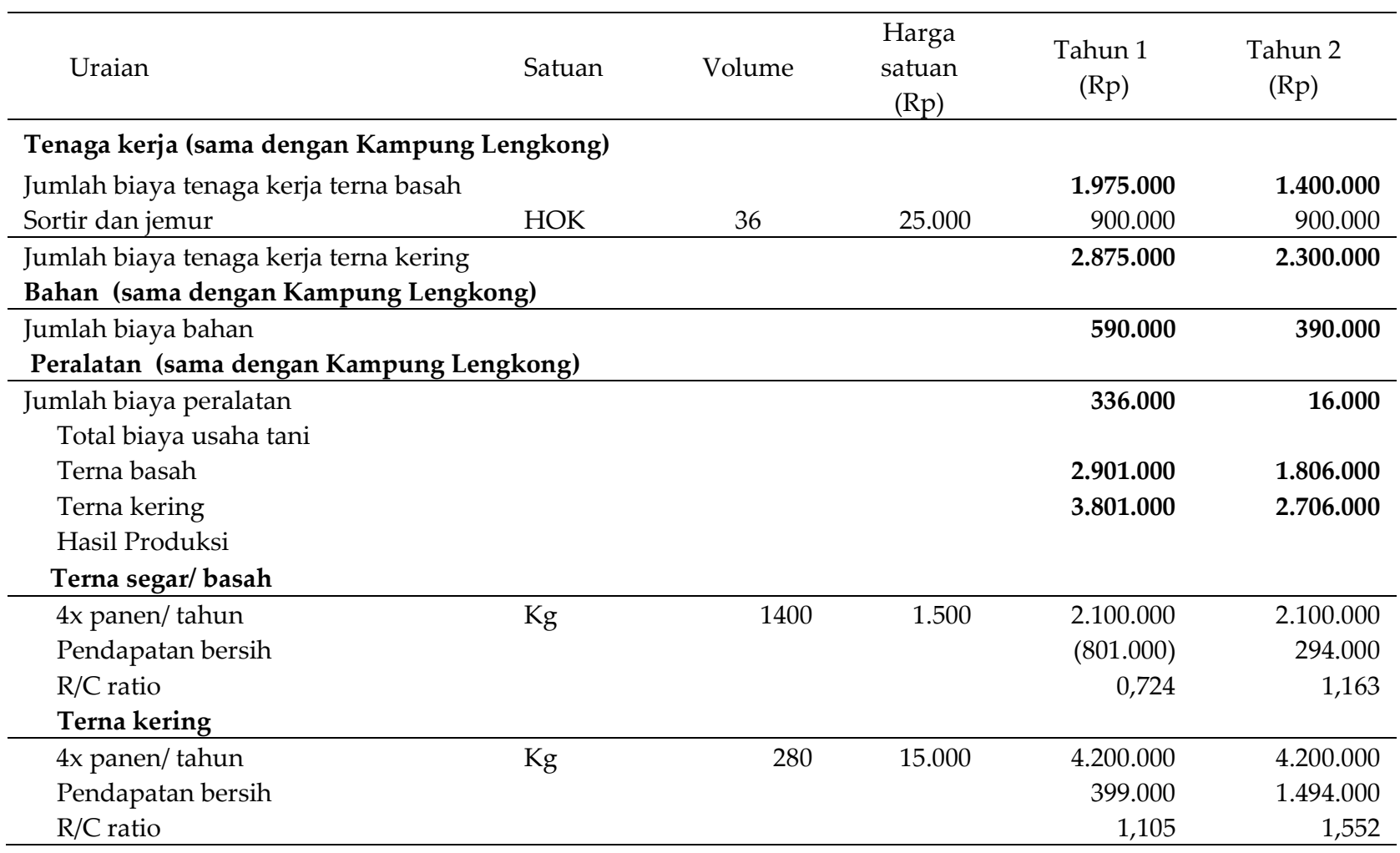

\section{Biaya Usaha Tani Kumis Kucing}

Berdasarkan perhitungan marjin pemasaran diperoleh hasil analisis marjin pemasaran di Kampung Ciwaluh masih sekitar 50\%, sedangkan di Kampung Lengkong melebihi sedikit diatas Kampung Lengkong yakni 58,36\% (Tabel 4). Besarnya biaya produksi di kedua saluran sama yakni $10,36 \%$. Gambaran ini menunjukan bahwa perbedaan harga di tingkat produsen terhadap harga di tingkat konsumen tidak terlalu besar dan biaya produksi rendah. Hal ini dimungkinkan, karena saluran pemasaran yang pendek dan komoditas yang diterima konsumen tidak mengalami banyak proses dan produsen memakai peralatan sederhana yang tidak diperhitungkan sebagai pengeluaran produksi.

Dari hasil perhitungan pada Tabel 5 diketahui bahwa petani sebagai produsen masih mendapatkan keuntungan tertinggi sekitar $80 \%$, meskipun kedudukan petani masih sebagai price taker. Lembaga pemasaran yang mendapatkan keuntungan terendah adalah pedagang pengumpul setingkat kampung, yakni $12,67 \%$. Hal ini bisa disebabkan fungsi pedagang pengumpul hanya sebagai perantara dan tidak melakukan proses terhadap komoditas yang dijual.

Kendali harga dan informasi konsumen, yang selama ini terjadi, berada pada pihak perantara (middleman) atau tengkulak yang memiliki kekuatan posisi tawar menawar (bargaining position). Petani produsen dan pedagang pengumpul hanya berhadapan dengan lembaga pemasaran setingkat diatasnya.

\section{Bagian Petani (Farmer's Share)}

Melalui perhitungan bagian petani (farmer's share) didapatkan bahwa bagian yang diterima produsen di Kampung Lengkong 52\% dan produsen di Kampung Ciwaluh menerima bagian $60 \%$. Berdasarkan margin pemasaran yang telah dianalisis, yakni 58,36\% di Kampung Lengkong dan 50,36\% di Kampung Ciwaluh, maka perolehan yang diterima petani memiliki hubungan positif. Ini dapat terjadi karena saluran riil di Desa Wates Jaya hanya melibatkan 1-2 lembaga pemasaran. Marjin pemasaran di tingkat konsumen dan produsen tidak terlalu besar, maka bagian petani menjadi cukup layak.

Kriteria efisiensi yang digunakan dalam penelitian ini adalah margin pemasaran, bagian petani (produsen) dan distribusi keuntungan (Tabel 6). Berdasarkan kriteria efisiensi pemasaran, maka saluran pemasaran riil di Desa Wates Jaya sudah termasuk kategori efisien. Faktorfaktor yang mendasarinya adalah pola saluran yang pendek, biaya produksi yang rendah dan proses pengolahan komoditas yang sederhana. 
Tabel 4. Hasil analisis margin pemasaran

\begin{tabular}{lcrr}
\hline Saluran & Harga di tingkat & Nilai (Rp/ kg) & Persen (\%) \\
\hline Kp. Lengkong & & & \\
1. Petani & Produksi & $10.410,71$ & $10,36(41,64)$ \\
2. Pengepul & Beli & $13.000,00$ & $(8,00)$ \\
3. Tengkulak & Beli & $15.000,00$ & $(40,00)$ \\
4. Eksportir (konsumen) & Akhir & $25.000,00$ & 100,00 \\
\hline Margin Pemasaran & & $14.589,29$ & 58,36 \\
\hline Kp. Ciwaluh & & & $10,36(49,64)$ \\
1. Petani & Produksi & $12.410,71$ & $(40,00)$ \\
2. Tengkulak & Beli & $15.000,00$ & 100,00 \\
3. Eksportir (konsumen) & Akhir & $25.000,00$ & 50,36 \\
\hline Margin Pemasaran & & $12.589,29$ & \\
\hline
\end{tabular}

Tabel 5. Hasil analisis margin keuntungan

\begin{tabular}{|c|c|c|c|c|c|}
\hline Saluran Pemasaran & $\begin{array}{c}\text { Biaya } \\
\text { produksi }(\mathrm{Rp} / \mathrm{kg})\end{array}$ & $\begin{array}{c}\text { Beli } \\
(\mathrm{Rp} / \mathrm{kg})\end{array}$ & $\begin{array}{c}\text { Jual } \\
(\mathrm{Rp} / \mathrm{kg})\end{array}$ & Keuntungan (Rp/ kg) & Persentase $(\%)$ \\
\hline & A & $\mathrm{B}$ & $\mathrm{C}$ & $d=c-(a+b)$ & $\mathrm{d} / \mathrm{c}^{*} 100 \%$ \\
\hline \multicolumn{6}{|l|}{ Kampung Lengkong } \\
\hline Petani & $2.589,29$ & & 13.000 & $10.410,71$ & 80,08 \\
\hline Pengepul & 100,00 & 13.000 & 15.000 & $1.900,00$ & 12,67 \\
\hline Tengkulak & 120,00 & 15.000 & 25.000 & $9.880,00$ & 39,52 \\
\hline Eksportir (konsumen) & & 25.000 & & & \\
\hline \multicolumn{6}{|l|}{ Kampung Ciwaluh } \\
\hline Petani & $2.589,29$ & & $15,000.00$ & $12.410,71$ & 82,74 \\
\hline Tengkulak & 200,00 & 15.000 & $25,000.00$ & $9.800,00$ & 39,20 \\
\hline Eksportir (konsumen) & & 25.000 & & & \\
\hline
\end{tabular}

Tabel 6. Kriteria efiensiensi saluran pemasaran

\begin{tabular}{lcc}
\hline Kriteria & \multicolumn{2}{c}{ Saluran Pemasaran } \\
\cline { 2 - 3 } & Kampung Lengkong & Kampung Ciwaluh \\
\hline Marjin pemasaran (\%) & 58,36 & 50,36 \\
Marjin keuntungan (\%) & 132 & 122 \\
Bagian petani (\%) & 52 & 60 \\
\hline
\end{tabular}

Penelitian komoditas tanaman obat kulit pulai oleh Effendi et al. (2011) dan kapulaga oleh Mulyana (2015) menghasilkan farmer's share tertinggi $80 \%$ dan $95,56 \%$. Hal ini bisa dicapai oleh saluran pemasaran yang pendek dan komoditas yang dijual sudah dalam bentuk kering.

Terbatasnya peran petani responden dalam proses pemasaran dipengaruhi oleh ketidakmampuan petani dalam menahan hasil panen, petani mementingkan akses tunai yang cepat dan enggan mencari alternatif saluran pemasaran lain disamping aksesibilitas informasi pasar tidak sampai ke tingkat produsen, maka saluran pemasaran kumis kucing dinilai dari analisis kuantitatif masuk dalam kategori efisien, namun jika dinilai dari minimnya aksesibilitas pasar tidak menguntungkan bagi petani.

\section{KESIMPULAN}

1. Saluran pemasaran kumis kucing di Kampung Lengkong dan Kampung Ciwaluh sangat sederhana. Petani tidak dapat berpindah ke saluran pemasaranlain yang memungkinkan untuk meningkatkan keuntungan, karena tidak memiliki akses pasar. Petani berada dalam kedudukan sebagai penerima harga (price taker) bukan price maker 
2. R/C ratio pada mata rantai di saluran pemasaran Kampung Ciwaluh berupa komoditas kering (simplisia) lebih menguntungkan, yakni 1,552. Efisiensi dalam saluran pemasaran kedua kampung sudah efisien, jika dilihat dari analisis marjin pemasaran dan marjin keuntungan, karena saluran pemasaran sangat pendek dan hanya memerlukan proses sangat sederhana. Persentase perolehan petani (farmer's share) cukup besar.

Berdasarkan temuan tersebut, dapat dikemukakan bahwa dari kondisi riil petani di Kampung Ciwaluh dan Kampung Lengkong dengan dua pola pemasaran berbeda masih belum memberi jaminan pasokan kumis kucing yang kontinyu dan belum beraninya petani untuk menjadikannya pendapatan utama.

\section{DAFTAR PUSTAKA}

Adnyana, I.K., F. Setiawan, M. Insannu. 2003. From ethnopharmacology to clinical study of Orthosiphon stamineus Benth. International Journal of Pharmacy and Pharmaceutical Sciences.Vol 5, Issue 3: 66-73.

De Silva, T. 2003. Industrial utilization of medicinal plants in developing countries. Di dalam: Bodeker G, Bhat KKS, Burley J, Vantomme $\mathrm{P}$, editor. Medicinal Plants for Forest Conservation and Health Care. Rome (IT): Food and Agriculture United Nations. hlm 34-44.

Effendi, R, A. Hafsari, Zuraida. 2011. Kajian Tata Niaga Kulit Pulai (Alstonia Scholaris) Sebagai Bahan Baku Obat Hipertensi (Antihipertensi) di Propinsi Jawa Tengah. Jurnal Penelitian Hutan Tanaman. Vol 8 (5): 315-321.

Hidayat, S. 2006. Tumbuhan Obat Langka di Pulau Jawa: Populasi \& Sebaran. Bogor (ID): Lembaga Ilmu Pengetahuan Indonesia, Pusat Konservasi Tumbuhan Kebun Raya Bogor.

Kartasubrata, J. 2010. Sukses Budidaya Tanaman Obat. Bogor (ID): IPB Press

[Kemenkes]. Peraturan Menteri Kesehatan Republik Indonesia Nomor 88 Tahun 2013 Tentang Rencana Induk Pengembangan Bahan Baku Obat Tradisional.
Kotler, P., G. Armstrong. 2006. Prinsip-Prinsip Pemasaran.Jilid 2 edisi 12. Jakarta (ID): Erlangga dari: Principles of Marketing

Mulyana, S. 2015. Kajian Alur Tata Niaga Kapulaga (Amomum cardomum L.) Sebagai Salah Satu Produk Hasil Hutan Rakyat Pola Agroforestry Di Kabupaten Tasikmalaya. Prosiding Seminar Nasional Agroforestry 2015.

Nasruddin, W., A. Musyadar. 2010. Tataniaga Pertanian. Tangerang (ID): Universitas Terbuka.

Pattamadilok, D., Y. Techadamrongsin, T. Boonruad, J. Bansiddhi. 2011. Chemical Specification of Orthosiphon aristatus (Blume) Miq. [Internet].[diunduh 2017 Feb 12] Tersedia pada thailand.digitaljournals. org/index.php.

Pribadi, E.R. 2009. Pasokan dan Permintaan Tanaman Obat Indonesia Serta Arah Penelitian dan Pengembangannya. Jurnal Perspektif. Vol 8 (1): 52-64.

Poerwanto, R., A.D. Susila. 2014. Teknologi Hortikultura. Bogor (ID): IPB Press

UNIDO [United Nations Industrial Development Organization]. 2006. Compendium of Medicinal and Aromatic Plants. [Internet] [diunduh pada 2017 November 12] Tersedia pada

https://www.unido.org/fileadmin/user_med ia/Publications/Pub_free/Compendium_of_ medicinal_and_aromatic_plants_volume_2. pdf.

Zuraida, L.A, H.S. Nuroniah. 2009. Perkembangan Biofarmaka Kehutanan. Di dalam: Tinambunan D, Wibowo A, editor. Bunga Rampai Biofarmaka Kehutanan Indonesia dari Tumbuhan Hutan untuk Keunggulan Bangsa dan Negara. Jakarta (ID): Pusat Penelitian dan Pengembangan Hutan Tanaman Kementerian Kehutanan. hlm 3-13.

Van Seters, A.P. 2003. Forest based medicines in traditional and cosmopolitan health care. Di dalam: Bodeker G, Bhat KKS, Burley J, Vantomme P, editor. Medicinal Plants for Forest Conservation and Health Care.Rome (IT): Food and Agriculture United Nations. hlm 5-11. 